\title{
Is there difference between men and women motorcyclists?
}

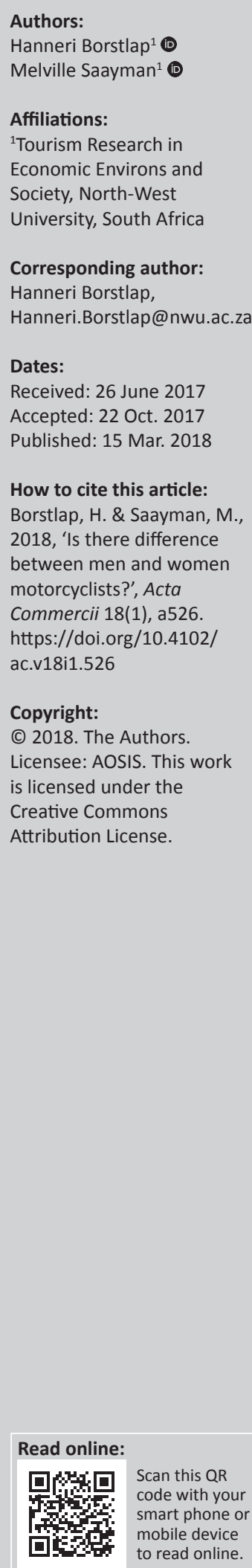

Orientation: To broaden the literature, identify markets and determine the motives of these markets within South Africa

Research purpose: The aim was to compare male and female motorcyclists' socio-demographic and behavioural characteristics at a motorcycle festival in South Africa.

Motivation of the study: There has been an increase in motorcycle sales and events and therefore motorcycle tourism, especially in South Africa. While from an international perspective, the socio-demographic and behavioural aspects of motorcyclists are well documented, what is lacking is literature on the behavioural aspects of motorcyclists and the differences between men and women.

Research design, approach and method: The study was descriptive, and data were primarily collected through self-administered questionnaires. Independent $t$-tests and cross-tabulation analyses were used.

Main findings: Four key motives were identified for attending the South Africa Bike Festival. The findings also confirmed that male and female motorcyclists differ from both sociodemographic and behavioural aspects and should be viewed as two distinctive segments. In addition, the research confirmed the importance of the age at which motorcyclists were exposed to motorcycling.

Practical managerial implications: Marketing campaigns should focus on both segments and should appeal to all motivational factors that have been identified.

Contribution: The study contributes to the motorcycle literature and provides a greater understanding of motorcyclists' behaviour and what motivates them to attend a motorcycle festival. The research provides guidelines to event organisers to effectively market such an event. The research also identifies different segments to this event, which provides more indications on what the motorcyclist looks like.

\section{Introduction}

Events play an integral part in the tourism industry and therefore a country's economy (Fenich, Herman \& Hashimoto 2012). South Africa is no exception when it comes to the promotion and hosting of events. One area or type of event that has experienced growth is motorcycle events, and this fact has led to the establishment of motorcycle tourism (Kruger, Viljoen \& Saayman 2014). Motorcycle tourism implies travel, in which the main motive is to experience any form of motorcycling, whether as a rider, passenger or spectator. Hooper-Greenhill (1994) explains that the reasons for mounting and creating special events such as motorcycle festivals are to attract and increase visitors, which ultimately contribute to the economic impact of the hosting community (Frey \& Busenhart 1996). It is crucial for policy makers, managers and marketing analysts to identify markets in order to assist them in planning and developing strategies (D'Urso et al. 2013; Swanson, Davis \& Zhao 2008) that will lead them to the answer, namely why motorcycle tourists attend these events (Kruger \& Saayman 2015). This knowledge is crucial for effective marketing (Fodess 1994).

Event organisers also host these events for specific causes such as riding for cancer, social implications and social responsibility; in addition, these events have an economic impact on the host area. For example, Rolling Thunder attracts up to 7500 motorcyclists, Laconia Motorcycle Week attracts 300000 to 400000 motorcyclists, Daytona Bike Week attracts almost 500000 motorcyclists and Sturgis Motorcycle Rally attracts between 450000 and 800000 motorcyclists. The size of this event is significant compared to some of the events in South Africa; for example, 
The Africa Bike Week that is held in Margate, KwaZuluNatal, South Africa, attracts approximately 25000 riders and spectators, and in 2013, it generated R110 million based on visitor spending alone (Scholtz et al. 2013). These events provide excellent opportunities to participate and observe aspects of the subculture of motorcyclists (Allen et al. 2003; McIntosh 2013). Even though many motorcycle events are held every year, little research has been conducted at these events, and even less is known about the gender differences, needs and behaviour of motorcyclists.

According to Natalier (2001) and Thompson (2009), female motorcyclists have different perceptions compared to male motorcyclists, but men and women describe the experience with similar terms and language, and both gender groups refer to their motorcycling experience as a cooperative experience between rider and the machine (Natalier 2001; Veno \& Winterhalder 2009). Veno and Winterhalder also state that although men and women have some similarities, each gender group has different expectations that are gender specific. This raises the question as to how men and women motorcyclists differ, what motivates them and what is their motorcycle behaviour? It is, therefore, the purpose of this article to compare male and female motorcyclists' sociodemographic aspects and behaviour by using one of South Africa's latest bike events, the South Africa Bike Festival, which was held at the newly revamped Kyalami Grand Prix Circuit in Johannesburg, South Africa. The South Africa Bike Festival is the first-ever motorcycle festival that has been organised in the country. This event took place from 27 to 29 May 2016 at the newly renovated Kyalami Grand Prix Circuit in Johannesburg in conjunction with Discovery Channel. The festival provided entertainment for everyone, ranging from Michelin Superbike School Circuit Test Rides, an extreme showcase by Le Rich Brothers, the BMW Motorrad Enduro Track for the adventure enthusiasts, a custom-bike competition, presentation of classic motorcycles by their proud owners and a charity run on Sunday (TREES 2016). Attendance of the event was very good with more than 24000 visitors, 124 industry-based exhibitors and 16 motorcycle manufacturers.

To identify who is likely to attend events such as those mentioned above, and in order to sustain such events by increasing the number of male and female riders, relevant marketing and information are needed, and hence this study (Kruger \& Saayman 2010).

\section{Literature review}

At the end of the 19th century, numerous inventors turned to the gasoline-powered vehicle, but one man, Charles Metz, manufactured a racing bicycle, which led to the establishment of the motorcycle. In 1900, the first race was recorded in the United States, and this led to two well-known brands of motorcycles that we know today, namely the Indian and Harley-Davidson motorcycles (founded in 1903). Although the Harley-Davidson Motor Company experienced greater success, supplying the military (First World War and Second
World War) and police with motorcycles (McIntosh 2013), a 'bad boy' image was associated with riders of these bikes. Motorcyclists in the 1970s were seen as deviants and involved in crime, drugs and violence (Natalier 2001).

Within the motorcycle culture, female motorcyclists were seen as inferior to men and were often the sole financial providers, whereas men could spend their time courting or performing club duties (Quinn 1987). According to Quinn, all documented research claims that women's subcultural role in motorcycling was characterised by patriarchal submission (as some scholars focus on women's autonomy and personal agency). Glamser (2003), though, reports that women learned about bikes from men. It was not until 1960 that Honda launched an advertisement with the slogan, 'You meet the nicest person on a Honda', featuring housewives and young couples, which evidently led to a respectable image of motorcyclists (McIntosh 2013). These changes and the public image are therefore more than just metal, plastic and rubber (Blankenship 2013).

While research conducted on motorcycling is available, it covers a wide range of topics, for example the ethnographic aspects (Conner 2009; Levingston \& Zimmerman 2003; Schouten \& McAlexander 1995), environmental aspects (Leong, Muttamara \& Laortanakul 2002), safety (Elliott et al. 2003; Weinzimmer et al. 2014), cultural significance (Maynard 2008; Packer \& Coffey 2004), charity runs (Rabinowitz 2007), adventure motorcycling (Price-Davies 2011), spirituality (Litton 2008), spending analysis (Kruger, Viljoen \& Saayman 2015) and motivation (Garber 2002; Hagen, Pardo \& Valente 2016; Kruger et al. 2014; Thompson \& Thompson 2014). Authors of studies on gender aspects of motorcycling include Cockburn and Ormond (1993); Hopper and Moore (1990); Kelkar and Nathan (2002); Martin, Schouten and McAlexander (2006); Mellström (2004); Meyer (2009); Oyesiku and Odufuwa (2002); Roster (2007); Thompson (2012); and Veno and Winterhalder (2009). Although the latter mentioned studies focus on gender, none of them compares the profile of a male and female rider. For a long time, motorcycling has predominantly been a male activity, but for women, it has been more of a socialisation activity with men (Martin et al. 2006). Today, motorcycling is both a transport and recreational activity (Huth, Fussl \& Risser 2014). Oyesiku and Odufuwa (2002) looked briefly at the gender perspectives in travel behaviour in Nigeria, with an emphasis on the mode of transport. Hanson and Hanson (1980) found that Swedish women, in contrast to their spouses, use scooters or small motorcycles more for shopping and domestic trips and less for social and recreational travel.

Over decades, there has been a dramatic change in transportation and thought. In general, very little research on the gender dimension exists in developing countries. In many developing countries in Asia and Africa, scooters are the main form of transport. They are easily manoeuvrable in big cities, they are economical and more women than men make use of them (Pinch \& Reimer 2012). These characteristics also work in tandem with the socio-economic (income, for 
example) and demographic characteristics of households (Hanson 1982; Stead et al. 2000; Steiner 1994).

Because of the economic situation in many countries, it has become the trend among parents to buy a scooter rather than a car for their children, as they are less expensive and easier to park. Another benefit is that in South Africa, one only needs to be 16 to obtain a motorcycle licence. Girls, especially rural girls, grow up with motorcycles, typically dirt bikes, to ride for sheer fun (Martin et al. 2006), as opposed to women, who slowly become interested in the motorcycles of their partners (who encourage and support them) and then even become riders. Moving from the pillion seat to the front has resulted in a quantum leap for women. Therefore, social-demographic and behavioural aspects have an influence on the motives of one's decision to attend events, which evidently have different outcomes (Figure 1), as every event differs from one to the next (Kruger \& Saayman 2015; Saayman \& Saayman 2015).

Levy (1959) refers to findings of previous research, claiming that consumer behaviour is rife with gender symbolism (Iyer \& Debevec 1989), a salient feature (Gould 1996) of gender identity, influencing consumer behaviour (Patterson \& Hogg 2004). Bristor and Ficher (1993) mention that one sometimes falls into a trap when trying to recognise the way in which consumer research is gendered. Riding a motorcycle might be characterised as gender tourism for women (Martin et al. 2006; Moore 1988).

Although many motorcyclists who were once rebellious settle down, marry and have families and careers, their love for motorcycles never goes away and more leisure time is spent enjoying this hobby. The demographic profile has changed from rebellious people to successful doctors, bankers and lawyers, to name but a few. They are also known as rich urban motorcyclists (RUBs), also known as Rubbies, which include women of all ages - even grandmothers (McIntosh 2013). The author further states that almost a quarter of the riders in the USA are women, with one in every 10 women owning a motorcycle. Today, women are the fastest growing segment among motorcycle riders (Knol 2010).

\begin{tabular}{|c|c|c|c|c|}
\hline Social demographic & $\Rightarrow$ & & \multirow{13}{*}{$\Rightarrow$} & Outcomes \\
\hline - Age & & • Escape & & - Greater \\
\hline - Gender & & - Adventure & & understanding \\
\hline - Education & & - Group aftiliation & & ol gender \\
\hline - Preferences & & - Lifestyle & & Pottor morketino \\
\hline - Income & & - Thrill of the ride & & \\
\hline - etc. & & - Status & & - Greater economir \\
\hline Behavioural & \multirow[t]{6}{*}{$\Rightarrow$} & & & impact \\
\hline - Club affiliation & & & & riders \\
\hline - Type of bike & & & & \\
\hline - Size of bike & & & & \\
\hline - Frequency of use & & & & \\
\hline - Spending & & & & \\
\hline
\end{tabular}

Source: Adapted Scholtz, M., Kruger, M., Saayman, M. \& Saayman, A., 2013, A marketing analysis and economic impact of the Africa Bike Week, unpublished research report, Tourism Research in Economic Environs and Society, North-West University, Potchefstroom.

FIGURE 1: Outcome-based analysis of motorcyclists.

\section{Research method}

This section will describe the design and questionnaire, sampling and statistical analysis.

\section{Design and questionnaire}

A structured self-completion questionnaire was designed to explore the objective of this study. The questionnaire was divided into two sections. Section A captured demographic details (e.g. gender, home language, age, education, home province, income and the level of education) and spending behaviour (e.g. the number of persons paid for, the number of tickets purchased, the length of stay and expenditure). Section B captured motivational and behavioural factors, measuring 18 items on a five-point Likert scale, where $1=$ not important at all, 2 = less important, 3 = important, $4=$ very important and $5=$ extremely important. This section also requested information specific to bike behaviour and interest. Questions included bike interest, type of bike owned and travel companions, tourist attractions visited, media consumption and whether they travelled to other similar events and rallies, and questions relating to the bike festival.

These questions were derived from similar festival research that was conducted previously and are therefore based on research conducted by various authors (Kruger, Viljoen \& Saayman 2013; Manners 2011; Saayman \& Saayman 2004).

\section{Sampling}

A convenience sampling method was used. Trained fieldworkers distributed the questionnaire to willing visitors at the festival, and they were briefed about the goal of the survey and the questionnaire. One hundred and eighty questionnaires were distributed daily over a 3-day period, as collecting data progressively allows for a more representative sample. To get an even number of questionnaires, 500 questionnaires were distributed over the 3 days, and 484 questionnaires were usable for this study. Israel (2009) explains that in a population of $24000(N), 484$ respondents $(n)$ are seen as a representative sample with an error rate of $7 \%$. To limit bias, a simple random sampling method was used within a stratified method where the fieldworkers followed specific guidelines to distribute questionnaires to visitors of different non-homogeneous age and gender groups. The questionnaires received back were, therefore, more than adequate and were therefore included in further analysis. According to Yeh and Lawrence (1996), a sample size of more than 200 respondents enhances reliability significance (Pallant 2016).

\section{Statistical analysis}

Data were captured using Microsoft Excel spreadsheets. Further analysis was done by means of Statistical Package for Social Science (SPSS) software (SPSS Inc. 2012) to determine the motivational factors, after which the data were analysed in three steps. 
Firstly, a general profile of the visitors to the South Africa Bike Festival was compiled. Secondly, by using factor analysis to identify the motivational factors, the Keiser-Meyer-Olkin measure of sampling was applied to the 18 motivational factors. The purpose was to determine whether the covariance matrix was suitable for factor analysis. Factors greater than 0.6 were considered (Steyn 2000), and a reliability coefficient was computed for each factor to estimate the consistency (Cronbach's alpha); all factors' reliability coefficients above 0.3 were considered as acceptable in this study. The average inter-item correlations were also computed as another measure of reliability and had to lie between 0.15 and 0.55 (Clark \& Watson 1995).

Lastly, independent $t$-tests, two-way frequency tables and a chi-square test were used to investigate any significant difference between men and women. Demographic and behavioural variables were used to examine whether there were statistically significant differences between the two gender groups. The results of the statistical analysis are discussed in the next section.

\section{Results}

\section{Profile of the respondents}

The majority of respondents who visited the festival were men $(67 \%)$, between the ages of 35 and 49 (35\%) years old and English speaking (52\%). These visitors were mainly from the provinces of Gauteng (78\%) and KwaZulu-Natal (5\%), bought Saturday passes (31\%) and were accompanied by their specific groups of friends (42\%). They travelled in groups of two persons and spent an average of R2000 per group. The visitors indicated that they attend rallies or other motorcycle events twice a year. The largest groups of respondents ( $27 \%$ each) indicated that they either ride a bike once a day or (at least) once a week, their preferred brand is BMW (20\%), and $41 \%$ of respondents indicated that they own at least one motorcycle. Of the respondents, $47 \%$ were exposed to motorcycles by their parents while they were between 0 and 10 years of age. Road bikes (50\%), sports $(43 \%)$, adventure $(35 \%)$, cruisers $(25 \%)$ and classic $(23 \%)$ are the categories that best describe respondents' interests. The largest group of respondents heard about the South Africa Bike Festival through word of mouth (39\%), followed by $27 \%$ who heard about it on Discovery Channel.

The Kaiser-Meyer-Olkin measure of sampling adequacy of 0.89 indicated that patterns of correlation are relatively compact and yield distinctive and reliable factors (Field 2005). The pattern matrix identified four factors (Table 1). These factors were labelled according to similar characteristics and explained $63 \%$ of the total variance. Factors were calculated as the average of all the items contributing to a specific factor to interpret them on the original five-point Likert scale of measurement in which 1 indicated not at all important, 2 slightly important, 3 important, 4 very important and 5 extremely important.

Factor scores have calculated the average of all items contributing to specific factors to be interpreted on a five-point

TABLE 1: Motivational factors.

\begin{tabular}{|c|c|c|c|c|}
\hline Motivational factors and items & Factor 1 & Factor 2 & Factor 3 & Factor 4 \\
\hline \multicolumn{5}{|l|}{ Factor 1: Lifestyle enthusiast } \\
\hline Because I am a motorcycle enthusiast & 0.841 & - & - & - \\
\hline To be part of this unique and exciting event & 0.760 & - & - & - \\
\hline To experience the South Africa Bike Festival attributes (shows and performances, etc.) & 0.710 & - & - & - \\
\hline Because attending bike events forms part of my lifestyle & 0.672 & - & - & - \\
\hline To visit the new, revamped Kyalami Grand Prix Circuit & 0.668 & - & - & - \\
\hline Because the festival provides an opportunity for me to test drive motorcycles & 0.600 & - & - & - \\
\hline To see the largest selection of motorcycle brands & 0.530 & - & - & - \\
\hline Because it is the perfect occasion to discover and purchase new/the latest gear/gadgets & 0.512 & - & - & - \\
\hline \multicolumn{5}{|l|}{ Factor 2: Event participant } \\
\hline To take part in the custom-built championships & - & -0.757 & - & - \\
\hline To take part in the charity ride & - & -0.738 & - & - \\
\hline To see an international celebrity & - & -0.735 & - & - \\
\hline To expose my children to motorcycling events & - & -0.733 & - & - \\
\hline To relax & - & - & 0.829 & - \\
\hline To spend time with my family/partner/spouse and friends & - & - & 0.809 & - \\
\hline To get away from my daily routine & - & - & 0.796 & - \\
\hline \multicolumn{5}{|l|}{ Factor 4: Socialiser } \\
\hline To meet new people with similar interests & - & - & - & -0.686 \\
\hline To take part in the pride owners' classic bike display & - & - & - & -0.611 \\
\hline Because it is a sociable event & - & - & - & -0.596 \\
\hline \multicolumn{5}{|l|}{ Total variance explained } \\
\hline Mean value & 0.455 & 0.521 & 0.560 & 0.516 \\
\hline Reliability coefficient & 0.870 & 0.813 & 0.792 & 0.762 \\
\hline Average inter-item correlation & 0.379 & 0.277 & 0.257 & 0.186 \\
\hline
\end{tabular}

$0.2-0.4=$ small effect; $0.5-0.8=$ medium effect; $>0.8=$ large effect. 
Likert scale. Table 1 shows the following motives: Factor 1 , lifestyle enthusiast, had the lowest mean value of 0.455 . This factor included statements such as being a motorcycle enthusiast; being part of a unique and exciting event; experiencing attributes (shows, performances, etc.) at the South Africa Bike Festival that form part of the motorcyclist's lifestyle; visiting the new, revamped Kyalami Grand Prix Circuit; having the opportunity to test drive motorcycles; seeing the largest selection of motorcycle brands; and this being the perfect occasion to discover and purchase new or the latest gear and gadgets.

Factor 2, event participant, received the second highest mean value (0.521). This factor included taking part in the custombuilt championships, taking part in the charity ride, seeing an international celebrity and exposing one's children to motorcycling events. Factor 3, escapist, revealed the highest mean value of 0.560 . This factor consists of the following aspects: relaxation, spending time with family/partners/ spouses and friends, and getting away from one's daily routine. Lastly, Factor 4, socialiser, received the second lowest mean value of 0.516 . This factor consists of meeting new people with similar interests, taking part in the pride owners' classic bike display and it being a sociable event.

\section{Results from the independent $t$-tests}

Independent $t$-tests were performed to determine whether significant differences existed between men and women in terms of socio-demographic and behavioural variables, including the motives. With regard to socio-demographic and behavioural aspects, Table 2 indicates that men and women differed significantly based on age $(p=0.032)$, income $(p=0.000)$, having children younger than 12 years old ( $p=0.026)$, having children between 12 and 18 years old $(p=0.008)$, number of motorcycles owned $(p=0.001)$ and age at which motorcyclists were exposed to motorcycles $(p=0.002)$.

The results revealed that men were older $(m=40.2)$, had a greater income $(m=5.25)$, had more children between 12 and 18 years old $(m=0.49)$, owned a greater number of motorcycles $(m=2.5)$ and were exposed to motorcycles at a younger age ( $m=11.35)$ compared to women. Men also had a significantly higher average of spending in the spending category. Men spent almost double on gear and merchandise (R696.10) compared to women (R359.63).

\section{Cross tabulations and chi-square test results}

From the information shown in Table 3, it is clear that men and women were statistics-wise significantly different in terms of travelling individually $(p=0.000)$ and with a partner $(p=0.000)$, buying a Sunday pass $(p=0.005)$, being a motorcycle collector $(p=0.005)$, riding a motorcycle every day $(p=0.002)$, being exposed to motorcycles by family $(p=0.004)$, having a motorcycle interest in a café racer $(p=0.001)$, quad $(p=0.000)$ and classic $(p=0.007)$, and hearing about the festival through Discovery Channel on television $(p=0.001)$ and in magazines $(p=0.011)$.

TABLE 2: Independent $t$-tests.

\begin{tabular}{|c|c|c|c|c|c|c|c|}
\hline \multirow[t]{2}{*}{ Variables } & \multicolumn{2}{|c|}{ Cluster 1: Men } & \multicolumn{2}{|c|}{ Cluster 2: Women } & \multirow[t]{2}{*}{$\boldsymbol{F}$} & \multirow[t]{2}{*}{ Sig $p$-value } & \multirow[t]{2}{*}{ Effect size } \\
\hline & Mean & Std dev & Mean & Std dev & & & \\
\hline Age & 40.10 & 13.35 & 37.21 & 12.24 & 2.093 & $0.032 *$ & 0.22 \\
\hline Income & 5.25 & 2.57 & 3.29 & 20.60 & 8.195 & $0.000 *$ & $0.76 *$ \\
\hline Group size & 4.20 & 4.08 & 4.71 & 4.03 & -1.273 & 0.202 & 0.13 \\
\hline Paying for children: & 2.15 & 1.92 & 2.19 & 1.59 & -0.221 & 0.825 & 0.02 \\
\hline Younger than 12 & 0.60 & 0.80 & 1.05 & 1.11 & -2.276 & $0.026^{*}$ & 0.41 \\
\hline $12-18$ years old & 0.49 & 0.77 & 0.18 & 0.45 & 2.708 & $0.008^{*}$ & 0.40 \\
\hline Above 18 years old & 0.94 & 1.70 & 1.05 & 1.88 & -0.294 & 0.769 & 0.06 \\
\hline Days & 1.23 & 0.56 & 1.21 & 0.54 & 0.280 & 0.780 & 0.03 \\
\hline Package & 479.32 & 671.73 & 425.54 & 582.18 & 0.723 & 0.471 & 0.08 \\
\hline Ticket & 31.85 & 141.72 & 40.46 & 172.91 & -0.453 & 0.651 & 0.05 \\
\hline Accommodation & 143.35 & 650.37 & 167.76 & 719.28 & -0.299 & 0.765 & 0.03 \\
\hline Transport & 130.73 & 443.66 & 140.43 & 480.76 & -0.177 & 0.860 & 0.02 \\
\hline Food and beverages & 261.20 & 413.95 & 312.48 & 454.21 & -0.994 & 0.322 & 0.11 \\
\hline Gear & 696.10 & 2268.91 & 359.63 & 1614.50 & 1.567 & 0.118 & 0.15 \\
\hline Clothes or merchandise & 290.82 & 226.39 & 226.39 & 582.75 & 0.858 & 0.391 & 0.08 \\
\hline Try, test rides & 61.88 & 189.59 & 32.78 & 110.66 & 1.781 & 0.076 & 0.15 \\
\hline Circuit test rides & 31.67 & 127.74 & 24.40 & 119.03 & 0.514 & 0.608 & 0.06 \\
\hline Sunday charity ride & 7.06 & 40.55 & 6.24 & 25.05 & 0.228 & 0.820 & 0.02 \\
\hline Number of motorcycles owned & 2.50 & 4.05 & 1.45 & 2.03 & 3.363 & $0.001 *$ & 0.26 \\
\hline Age exposed & 11.38 & 6.82 & 14.31 & 93.51 & -3.190 & $0.002 *$ & 0.31 \\
\hline Motive 1 & 3.58 & 0.90 & 3.43 & 1.08 & 1.429 & 0.154 & 0.14 \\
\hline Motive 2 & 2.42 & 1.22 & 2.34 & 1.18 & 0.628 & 0.531 & 0.07 \\
\hline Motive 3 & 3.60 & 1.13 & 3.74 & 0.98 & -1.277 & 0.203 & 0.12 \\
\hline Motive 4 & 2.96 & 1.13 & 2.85 & 1.14 & 0.831 & 0.407 & 0.09 \\
\hline Spending & 1834.50 & 2977.38 & 1500.30 & 2729.20 & 1.092 & 0.267 & 0.11 \\
\hline
\end{tabular}

$*$, indicated which factors loaded as significant.

Std dev, standard deviation is a measure of how spread out numbers are. 
TABLE 3: Cross tabulations of socio-demographic characteristics.

\begin{tabular}{|c|c|c|c|c|c|c|}
\hline \multirow[t]{2}{*}{ Characteristics } & \multicolumn{2}{|c|}{ Gender cluster } & \multirow[t]{2}{*}{ Chi-square value } & \multirow[t]{2}{*}{ Df } & \multirow[t]{2}{*}{ Sig level } & \multirow[t]{2}{*}{ Phi-value } \\
\hline & Men (\%) & Women (\%) & & & & \\
\hline Home language & - & - & 1.967 & 2 & 0.374 & 0.066 \\
\hline Afrikaans & 43.3 & 44.3 & - & - & - & - \\
\hline English & 53.4 & 49.7 & - & - & - & - \\
\hline Other (specify) & 3.4 & 6.0 & - & - & - & - \\
\hline \multicolumn{7}{|l|}{ Travelling } \\
\hline With a club & 9.6 & 13.2 & 1.356 & 1 & 0.244 & 0.055 \\
\hline With a group of friends & 44.1 & 37.7 & 1.686 & 1 & 0.194 & 0.061 \\
\hline With a partner & 13.6 & 31.1 & 19.652 & 1 & $0.000 *$ & 0.209 \\
\hline With a spouse & 13.6 & 17.9 & 1.427 & 1 & 0.232 & 0.56 \\
\hline \multicolumn{7}{|l|}{ Entrance package bought } \\
\hline Family package & 4.5 & 8.2 & 2.537 & 1 & 0.111 & 0.076 \\
\hline Three-day pass & 4.5 & 6.2 & 0.586 & 1 & 0.444 & 0.037 \\
\hline Saturday pass & 27.8 & 36.3 & 3.278 & 1 & $0.070 * * *$ & 0.087 \\
\hline Sunday pass & 20.6 & 32.9 & 7.852 & 1 & $0.005 *$ & 0.134 \\
\hline VIP pit-roof village & 24.4 & 15.1 & 5.052 & 1 & $0.025 *$ & 0.108 \\
\hline Highest level of qualification & - & - & - & 5 & 0.645 & 0.087 \\
\hline Scholar & 1.7 & 1.4 & - & - & - & - \\
\hline Matric & 24.8 & 29.1 & - & - & - & - \\
\hline Diploma, degree & 45 & 48.2 & - & - & - & - \\
\hline Postgraduate & 14.1 & 9.2 & - & - & - & - \\
\hline Professional & 11.1 & 8.5 & - & - & - & - \\
\hline Other (specify) & 3.4 & 2.5 & - & - & - & - \\
\hline Province & - & - & 7.822 & 9 & 0.552 & 0.131 \\
\hline Gauteng & 77.9 & 77.3 & - & - & - & - \\
\hline Free State & 2.9 & 2 & - & - & - & - \\
\hline North West & 1.3 & 4 & - & - & - & - \\
\hline Mpumalanga & 2.9 & 4.7 & - & - & - & - \\
\hline Northern Cape & 1.3 & 0 & - & - & - & - \\
\hline Western Cape & 2.9 & 2 & - & - & - & - \\
\hline Limpopo & 1.6 & 0.7 & - & - & - & - \\
\hline Other & 3.3 & 2.7 & - & - & - & - \\
\hline Motorcycle collector & 30.7 & 18.1 & 7.886 & 1 & $0.005 *$ & 0.135 \\
\hline Events attended per year & - & - & 30.778 & 24 & 0.160 & 0.256 \\
\hline \multicolumn{7}{|l|}{ Ride your bike } \\
\hline Everyday & 31.2 & 16.2 & 9.312 & 1 & $0.002 *$ & 0.156 \\
\hline At least once a week & 26.7 & 25.6 & 0.046 & 1 & 0.830 & 0.011 \\
\hline A few times a week & 14 & 11.1 & 0.600 & 1 & 0.439 & 0.040 \\
\hline Weekends & 17 & 19.7 & 0.398 & 1 & 0.528 & 0.032 \\
\hline Monthly & 11.7 & 19.7 & 4.237 & 1 & $0.040 * *$ & 0.105 \\
\hline \multicolumn{7}{|c|}{ Who exposed you to motorcycles? } \\
\hline Parents & 44 & 39 & 0.949 & 1 & 0.330 & 0.47 \\
\hline Siblings & 11 & 9.2 & 0.317 & 1 & 0.573 & 0.027 \\
\hline Family members & 19.9 & 32.6 & 8.372 & 1 & $0.004 *$ & 0.141 \\
\hline Friends & 37.6 & 39.7 & 0.180 & 1 & 0.671 & 0.021 \\
\hline Media & 11 & 7.1 & 1.634 & 1 & 0.201 & 0.062 \\
\hline Ride outside South Africa & 31.7 & 19.7 & 6.298 & 1 & 0.012 & 0.126 \\
\hline \multicolumn{7}{|l|}{ Motorcycle interest } \\
\hline Scooters and mopeds & 7.2 & 8.3 & 0.138 & 1 & 0.710 & 0.018 \\
\hline Sports & 45 & 38.3 & 1.638 & 1 & 0.201 & 0.062 \\
\hline Speciality and custom & 15.2 & 15.8 & 0.027 & 1 & 0.870 & 0.008 \\
\hline Café racer & 24.1 & 9.8 & 11.928 & 1 & $0.001 *$ & 0.168 \\
\hline Off-road trails & 19.3 & 17.4 & 0.212 & 1 & 0.645 & 0.022 \\
\hline Cruisers & 25.5 & 22.6 & 0.431 & 1 & 0.511 & 0.32 \\
\hline Quads & 9.3 & 22 & 12.631 & 1 & $0.000 *$ & 0.173 \\
\hline
\end{tabular}


TABLE 3(Continues...): Cross tabulations of socio-demographic characteristics.

\begin{tabular}{|c|c|c|c|c|c|c|}
\hline \multirow[t]{2}{*}{ Characteristics } & \multicolumn{2}{|c|}{ Gender cluster } & \multirow[t]{2}{*}{ Chi-square value } & \multirow[t]{2}{*}{ Df } & \multirow[t]{2}{*}{ Sig level } & \multirow[t]{2}{*}{ Phi-value } \\
\hline & Men (\%) & Women (\%) & & & & \\
\hline Road bikes & 48.6 & 47.4 & 0.057 & 1 & 0.811 & 0.012 \\
\hline Adventure & 35.9 & 30.1 & 1.360 & 1 & 0.244 & 0.57 \\
\hline Classic & 26.9 & 15 & 7.204 & 1 & $0.007 *$ & 0.131 \\
\hline \multicolumn{7}{|l|}{ Heard about the festival through } \\
\hline Discovery Channel & 27.3 & 12.2 & 11.683 & 1 & $0.001 *$ & 0.169 \\
\hline Television (other) & 14.7 & 8.4 & 3.237 & 1 & 0.72 & 0.089 \\
\hline Radio & 12.6 & 10.7 & 0.306 & 1 & 0.580 & 0.027 \\
\hline Website & 17.3 & 12.2 & 1.759 & 1 & 0.185 & 0.066 \\
\hline Email & 11.2 & 6.95 & 1.849 & 1 & 0.174 & 0.067 \\
\hline Magazines & 20.1 & 10 & 6.486 & 1 & $0.011 *$ & 0.126 \\
\hline Newspaper & 7.2 & 5.3 & 0.495 & 1 & 0.482 & 0.035 \\
\hline Social media (e.g. Facebook, Twitter) & 25.3 & 28.2 & 0.406 & 1 & 0.524 & 0.032 \\
\hline Word of mouth & 34.5 & 35.9 & 0.071 & 1 & 0.790 & 0.013 \\
\hline Yes & 96.8 & 97.1 & 0.035 & 1 & 0.852 & 0.009 \\
\hline
\end{tabular}

*, Phi: 0.1 = small; **, 0.3 = medium; ***, 0.5 large.

\section{Findings and implications}

Based on the results, this research revealed the following findings and implications: the first finding reveals four key motives for attending the South Africa Bike Festival. This combination of motives has not been found in the literature before. Escapist has the highest mean value and confirms the findings in the literature that this motive is the most common motive in the festival and tourism literature (Kim, Lee \& Klenosky 2003; Kruger \& Saayman 2010; Saayman \& Saayman 2009). Crowther (2007), Kruger et al. (2014) and Price-Davies (2011) have also identified escape as a motive and emphasise that the marketing approach should consider the differences when developing the message for different segments (Kruger \& Saayman 2015). The marketing campaign should not focus on only one of the segments (motivational factors), but should rather focus on all of them, namely relaxation, escape, having fun with friends and family, and event-specific features.

The second finding concerns the profiles of the visitors to the South Africa Bike Festival and furthermore confirms the findings by Broughton (2007) and Miller (2012), namely that there is indeed a difference between male and female motorcyclists and that they should be viewed as two distinct segments, both with different motives and different outcomes, as indicated in Figure 1. Motorcyclists include people from all socio-economic strata, cultural backgrounds and social positions; the diversity in demographics is greater than it has ever been before. Event organisers should market these types of events among motorcyclists with broad economic, racial and political backgrounds. As the main differences between men and women are based on socio-demographic and behavioural characteristics, one cannot assume that these types of motorcycle events are homogeneous (Broughton 2007). Event organisers should keep this in mind when promoting to men and women, as women are the fastest growing demographic participants in male-dominated domains (Little 2002; Nisbet 1988; Warren 1996).
With regard to the results of the socio-demographic aspects of age, income and dependants, it has been shown that the average age of male visitors is 40 years. Broughton (2007) and Miller (2012) found that visitors attending motorcycle events are more mature and between 40 and 50 years old, as opposed to the visitors at the South Africa Bike Festival, who are between 37 and 40 years old (women and men, respectively). Research has shown that both men and women are still young; this is also known as the new motorcyclist culture (Austin 2009; Gagne \& Austin 2002; Murphy \& Patterson 2011; Thompson 2009). Men spend more money on gear and gadgets than women, which supports the findings of Mehmetoglu (2007) and Pouta, Neuvonen and Sievänen (2006); however, Graggs and Schofield (2009) contradict this finding.

Furthermore, research has shown that both men and women are educated (Box 2007), being well-established doctors, lawyers, bankers and blue-collar workers, also known as RUBs (McIntosh 2013). Van Vlerah and Lea (2013) add that motorcycling needs to keep up with the changing clientele; the authors add that as the economic landscape of motorcycling continues to change, attracting new riders, the culture shift is inevitable. By using this information, a more focused marketing campaign can be created to exploit the market attending these types of events.

Regarding behavioural differences, the following factors were the most significant differences between men and women: motorcycles owned, age exposed to motorcycles, travelling behaviour, entrance package bought, whether the motorcyclists were motorcycle collectors or not, frequency of riding, who exposed them to motorcycles, motorcycle interest and where they heard about the festival.

It was found that the majority of men travelled alone to the event as opposed to the women, who travelled with partners. The reason for this may be that most women attending the festival were passengers. This confirms the statement by Jackson and Henderson (1995) that somehow women only 
participate as passengers because they have to deal with specific constraints, a lack of skill, the cost of participation and family responsibility. Thompson's (2012) study revealed that although most women had started out riding in groups of two or more, they eventually made the transition to riding alone. Although motorcycling is seen as a male-dominated field, women feel the same sense of belonging, being loved, freedom and independence that gives them escape from the everyday routine and responsibility. The message to these women should portray motorcycling as a fulfilment of these needs that are so desired by them with an emphasis or focus on the thrill, relaxation, escape, fun and adventure.

Studies have indicated that both men and women were exposed to motorcycles in their teens; this is confirmed by studies of Auster (2001), Glamser (2003) and Roster (2007). Women, though, were exposed to motorcycles by friends as opposed to men, who were exposed to motorcycles by their parents. Glamser's (2003) study shows that out of 53 women participating in the survey, 49 identified spouses, boyfriends or fathers as the persons who initiated them to the culture of motorcycling. This finding highlights the importance of exposure to motorcycle events to promote the lifestyle and culture associated with attending these types of events. As mentioned before, marketers need to include activities for families when planning events such as these in order to promote the motorcycling culture among young adults and children. More motorcycling events facilitate more exposure and a greater appreciation of motorcycling among the youth. To expand and exploit this market, children should therefore be exposed to these types of events to a greater extent.

With regard to the source from where participants heard about the festival, Discovery Channel (a British channel broadcasting on DSTV [Digital Satellite Television]) and magazines were the most significant sources of information. This finding contradicts the findings in the literature that the majority of the festivalgoers heard about the event by word of mouth (Kruger \& Saayman 2015; Kruger et al. 2013). Managers and marketers need to keep this in mind when advertising and should focus on a twofold strategy, one to attract men and the other to attract women by means of television and printed media, as this is the preferred media source for men and women attending the festival. If the event is a great success, the motorcycling market will also grow.

\section{Conclusions}

The purpose of this research was to determine the differences between men and women in the socio-demographic and behavioural characteristics at a motorcycling festival in South Africa, which have proved to be significant. It was the first time that motorcyclists at a motorcycling festival were analysed according to gender, thereby helping to fill the gap in motorcycling literature regarding the behaviour of male and female riders. The findings imply that for organisers, event planners and marketers, the marketing message should be developed according to the different segments.
The study contributes to the motorcycling literature and provides a greater understanding of especially female motorcyclists' behaviour. This information can be used to broaden motorcycling tourism in order to attract more young persons and women to these types of events.

Travelling to the destination may be far more important than the destination itself, as this is the case for those whose leisure pursuit is motorcycling, because these riders have a reasonable disposable income, are social and move around in groups.

Lastly, the results of this research can be used to expand motorcycle tourism in South Africa. For example, as the majority of motorcyclists are exposed to motorcycles at a young age, this fact is worth exploiting in order to know what their perceptions of motorcycling are. Second-hand motorcycling shops can also focus on portraying the marketing message to appeal to the younger market. This is necessary in order to obtain a greater understanding of the economics of motorcycling. The results can also be used to research strategies for growing motorcycling tourism. More studies on motorcycle events and motorcyclists are recommended to expand the existing literature on this topic in order to enhance motorcycle tourism in South Africa, both regionally and nationally. This emphasises that more research on motorcyclists' travel behaviour is required in order to understand where they travel to and how long they stay at different destinations.

\section{Acknowledgements}

The authors would like to thank Clarion Events for the opportunity to conduct research at the South Africa Bike Festival.

\section{Competing interests}

The authors declare that they have no financial or personal relationships that may have influenced them inappropriately in writing this article.

\section{Authors' contributions}

H.B. was the project leader and was responsible for designing the questionnaire, conducting the survey at the event and writing of the article. M.S. was responsible for intellectual contribution to design the questionnaire, conducting the survey at the event and writing of this article.

\section{References}

Allen, J., Van Delden, R., Foley, C. \& Arnold, M.J., 2003, 'Assessing bikers' extraordinary experiences, sub-cultural values, self-monitoring and self-presentation at bike week: A preliminary model', in Proceedings, American Marketing Association 2003 Winter Educators' Conference, pp. 53-59.

Auster, C., 2001, 'Transcending potential antecedent leisure constraints: The case of woman motorcycle operators', Journal of Leisure Research 33(3), 272-298.

Austin, D., 2009, 'Ritual and boundary distinction in a recreational community: A case study of motorcycle rallies and riders', Qualitative Sociology Review 5(2), 70-93.

Blankenship, P.D., 2013, Gender, style technology: The changing landscape of motorcycling culture, University of Texas, Arlington, TX.

Bristor, J.M. \& Fisher, E., 1993, 'Feminist thought: Implications for consumer research', Journal of Consumer Research 19(4), 518-536. https://doi.org/10.1086/209320 
Broughton, P.S., 2007, 'Risk and enjoyment in powered two wheeler use', PhD thesis, Transport Research Institute, Napier University, Edinburgh.

Box, T., 2007, 'Biker chic', Dallas Morning News, 24 June, 1d:6D.

Clark, L.A. \& Watson, D., 1995, 'Constructing validity: Basic issues in objective scale development', Psychological Assessment 7(3), 267-282. https://doi.org/10.1037/ 1040-3590.7.3.309

Cockburn, C. \& Ormond, S., 1993, Gender and technology in the making, Sage, London.

Conner, M.S., 2009, 'First-wave feminist struggles in black motorcycle clubs', International Journal of Motorcycle Studies 5(2), viewed 10 November 2016, from http:ijms.ova.edu/Fall2009/IJMS_Artcl.Conner.html

Crowther, G., 2007, 'Embodied experiences of motorcycling at the isle of man TT races', International Journal of Motorcycle Studies, viewed 10 November 2016, from http://ijms.nova.edu/November2007TT/IJMS_Artcl.Crowther.html

D’Urso, P., De Giovanni, L., Disegna, M. \& Massari, P., 2013, 'Bagged clustering and its application to tourism market segmentation', Expert System with Applications 40(12), 4944-4956. https://doi.org/10.1016/j.eswa.2013.03.005

Elliott, M.A., Baughan, C.J., Broughton, J., Chinn, B., Grayson, G.B., Knowles, J. et al., 2003, Motorcycle safety: A scoping study, TRL Report 581, Transport Research Laboratory, Crowthorne.

Fenich, G.G., Herman, U.P. \& Hashimoto, K., 2012, 'Toward a framework for the development of qualifications in meetings, expositions, events, and conventions in South Africa', Journal of Convention and Event Tourism 13, 39-47. https://doi.org/ 10.1080/15470148.2012.651783

Field, A., 2005, Discovering statistics using SPSS, Sage, London.

Fodess, D., 1994, 'Measuring tourist motivations', Annals of Tourism Research 21(3), 555-581. https://doi.org/10.1016/0160-7383(94)90120-1

Frey, B.S. \& Busenhart, I., 1996, 'Special exhibitions and festivals. Culture's booming path to glory', Contributions to Economic Analysis 237, 275-302.

Gagne, P. \& Austin, D.M., 2002, 'Doing gender and negotiating equity: Woman motorcyclists in male dominated subculture', paper presented at Annual Meetings of the Pacific Sociological Association, Vancouver, BC, Canada, 18th-21st July.

Garber, L., 2002, Woman who ride: The psyche of the female motorcyclist, Pacifica Graduate University, Carpentaria.

Glamser, F., 2003, 'Woman motorcyclists: Childhood foundations and adult pathways', Free Inquiry in Creative Sociology 31(2), 183-193.

Gould, S.J., 1996, 'Gender identity and gender salience: A dual-path, person-situation approach to gender effects on consumer research', Advances in Consumer Research 23, 478-483.

Graggs, R. \& Schofield, P., 2009, 'Expenditure based segmentation and visitor profiling the quays in Salford, UK', Tourism Economics 15(1), 243-260. https://doi.org/ the quays in Salford, UK', Tourism
$10.5367 / 000000009787536753$

Hagen, J.X., Pardo, C. \& Valente, J.B., 2016, 'Motivations for motorcycle use for urban travel in Latin America: A qualitative study', Transport Policy 49, 93-104. https:// doi.org/10.1016/j.tranpol.2016.04.010

Hanson, S. 1982, 'The determinants of daily travel-activity patterns: Relative location and sociodemographic factors', Urban Geography 3(3), 179-202.

Hanson, S. \& Hanson, P., 1980, 'The travel activity patterns of urban residents: Dimensions and relationships to sociodemographic characteristics', Economic Geography 57(4), 332-347. https://doi.org/10.2307/144213

Hooper-Greenhill, E., 1994, 'Museums education: Past present and future', in R. Miles $\&$ L. Zavala (eds.), Towards the museum of the future; New European perspectives, pp. 133-149, Routledge, London.

Hopper, C. \& Moore, J., 1990, 'Woman in outlaw motorcycle gangs', Journal of Contemporary Ethnography 18(4), 363-387. https://doi.org/10.1177/08912419 0018004001

Huth, V., Fussl, E. \& Risser, R., 2014, 'Motorcycle rider's perceptions, attitudes and strategies: Findings from a focus group study', Transportation Research Part $F$ 25(A), 74-85. https://doi.org/10.1016/j.trf.2014.05.004

Israel, G.D., 2009, Determining sample size, University of Florida, Gainesville, FL.

Iyer, E. \& Debevec, K., 1989, 'Bases for the foundation of products gender images', in J.M. Hawes \& J. Akron (eds.), Developments in marketing science, pp. 38-42, Academy of Marketing Science, Orlando, FL.

Jackson, E.L. \& Henderson, K.A., 1995, 'Gender-based analysis of leisure constraints', Leisure Sciences 17(1), 31-51. https://doi.org/10.1080/01490409509513241

Kelkar, G. \& Nathan, D., 2002, 'Gender relations and technology changes in Asia', Current Sociology 50(3), 427-441. https://doi.org/10.1177/0011392102050003008

Kim, S.S., Lee, C.K. \& Klenosky, D.B., 2003, 'The influence of push and pull factors at Korean national parks', Tourism Management 24(2), 169-180. https://doi.org/ 10.1016/S0261-5177(02)00059-6

Knol, 2010, The US motorcycle market, viewed 10 September 2011, from http://knol. google.com/k/the-u-s-motorcycle-market\#

Kruger, M. \& Saayman, M., 2010, 'Travel motivation of tourists to Kruger and Tsitsikamma National Parks: A comparative study', South African Journal of Wildlife Research 40(1), 93-102. https://doi.org/10.3957/056.040.0106

Kruger, M. \& Saayman, M., 2015, 'Attendance at the U2 concert: Is it a case of "This is a Man's World?"', Event Management 19(1), 15-32. https://doi.org/10.3727/152 $599515 \times 14229071392864$

Kruger, M., Viljoen, A. \& Saayman, M., 2013, 'Who pays to view wildflowers in South Africa?', Journal of Ecotourism 12(3), 146-164. https://doi.org/10.1080/1472404 9.2013 .871286
Kruger, M., Viljoen, A. \& Saayman, M., 2014, 'What drives bikers to attend a motorcycling event?', African Journal of Hospitality, Tourism and Leisure 3(1), $1-21$.

Kruger, M., Viljoen, A. \& Saayman, M., 2015, 'Who are the big spenders at a motorcycle event?', Journal of Economic and Financial Sciences 8(2), 327-353.

Leong, S.T., Muttamara, S. \& Laortanakul, P., 2002, 'Influence of benzene emission from motorcycle on Bangkok air quality', Atmospheric Environment 36(4), 651-661. https://doi.org/10.1016/S1352-2310(01)00474-5

Levingston, T. \& Zimmerman, K., 2013, Soul on bikes: The East Bay Dragons MC and the Black Biker Set, Motorbooks International, Osceola, WI.

Levy, S.J., 1959, 'Symbols for sale', Harvard Business Review 37(4), 117-124.

Little, D.E., 2002, 'Women and adventure recreation: Reconstructing leisure constraints and adventure experiences to negotiate continuing participation', Journal of Leisure Research 34(2), 157.

Litton, A., 2008, 'Finding the Zen in motorcycling', International Journal of Motorcycle Studies 4(2), Fall, viewed 03 October 2016, from http://ijms.nova.edu/Fall2008/ IJMS_Artcl.Litton.html

Manners, B., 2011, 'The critical success factors for managing the visitor experience at a major musical event', doctoral dissertation, North-West University.

Martin, D.M., Schouten, J.W. \& McAlexander, J.H., 2006, 'Claiming the throttle: Multiple femininities in a hypermasculine subculture', Consumption, Markets and Culture 9(3), 171-205. https://doi.org/10.1080/10253860600772206

Maynard, J.R.A., 2008, 'Between man and machine: A socio-historical analysis of masculinity in North American motorcycling culture', master's thesis, Queen's University Kingston.

McIntosh, P., 2013, Motorcycles on the move, In English Teaching Forum, vol. 51, No. 3 , pp. 36-45, US Department of State, Bureau of Educational and Cultural Affairs, Office of English Language Programs, Washington, DC.

Mehmetoglu, M., 2007, 'Nature-based tourists: The relationship between their trip expenditures and activities', Journal of Sustainable Tourism 15(2), 200-215. https://doi.org/10.2167/jost642.0

Mellström, U., 2004, 'Machines and masculine subjectivity technology as an integral part of men's life experiences', Men and Masculinities 6(4), 368-382. https://doi. org/10.1177/1097184X03260960

Meyer, P., 2009, “We're just women who like to ride": An ethnographic journey on a woman's motorcycle', master's dissertation, Southern Illinois University Carbondale.

Miller, P.M., 2012, Harley Davidson in China. An American icon revs up its fan base and sales in China, viewed 11 August 2016, from www.chinabusinessreview.com/ harley-davidson-in-china/

Moore, S., 1988, 'Getting a bit of the other-the pimps of postmodernism', in R. Chapman \& J. Rutherford (eds.), Male order: Unwrapping masculinity, pp. 165-192, Lawrence and Wishart, London.

Murphy, S. \& Patterson, M., 2011, 'Motorcycling edgework: A practice theory perspective', Journal of Marketing Management 27(13-14), 1322-1340. https:// doi.org/10.1080/0267257X.2011.627366

Natalier, K., 2001, 'Motorcyclists' interpretations of risk and hazard', Journal of Sociology 37(1), 65-80. https://doi.org/10.1177/144078301128756201

Nisbet, J., 1988, 'Is it the men, the mud or the media?', New Zealand Journal of Health, Physical Education and Recreation 21, 13-14.

Oyesiku, O.O. \& Odufuwa, B.O., 2002, 'Gender perspectives in travel behaviour of motorcycle passengers in Nigerian intermediate cities', in X. Godard \& I. Fatonzoun (eds.), Urban mobility for all, pp. 13-19, AA Balkema, Lisse, The Netherlands.

Packer, J. \& Coffey, M.K., 2004, 'Hogging the road: Cultural governance and the citizen cyclist 1', Cultural Studies 18(5), 641-674. https://doi.org/10.1080/09502380420 00260342

Pallant, J., 2016, SPSS survival manual: A step-by-step guide to data analysis using IBM SPSS, Allen \& Unwin, Sydney.

Patterson, C.E. \& Hogg, M.K., 2004, 'Gender identity, gender salience and symbolic consumption', in GCB-Gender and Consumer Behavior 7, 1-33.

Pinch, P., \& Reimer, S., 2012, 'Moto-mobilities: Geographies of the motorcycle and motorcyclists', Mobilities 7(3), 439-457.

Price-Davies, E., 2011, 'Adventure motorcycling: The tourist gaze', International Journal of Motorcycle Studies 7(1), viewed 11 August 2016, from http://ijms.nova. edu/Spring2011/IJMS_Artcl.PriceDavies.html

Pouta, E., Neuvonen, M. \& Sievänen, T., 2006, 'Determinants of nature trip expenditures in Southern Finland-implications for nature tourism development', Scandinavian Journal of Hospitality and Tourism 6(2), 118-135. https://doi. org/10.1080/15022250600658937

Quinn, J.F., 1987, 'Sex roles and hedonism among members of "outlaw" motorcycle clubs', Deviant Behavior 8(1), 47-63. https://doi.org/10.1080/01639625.1987. clubs', Devid

Rabinowitz, I., 2007, 'A generous imaginary: Contingencies of value in the South African Charity run', International Journal of Motorcycle Studies, viewed African Charity run', International Journal of Motorcycle Studies, viewed 03 Octo
html

Roster, C.A., 2007, "Girl power" and participation in macho recreation: The case of female Harley riders', Leisure Sciences 29(5), 443-461. https://doi.org/10.1080/ female Harley riders',
01490400701544626 
Saayman, M. \& Saayman, A., 2004, 'Economic impact of cultural events', South African Journal of Economic and Management Sciences 7(4), 629-641. https://doi. org/10.4102/sajems.v7i4.1294

Saayman, M. \& Saayman, A., 2009, 'Why travel motivation and socio-demographics matter in managing a national park', Koedoe 51(1), 1-9. https://doi.org/10.4102/ koedoe.v51i1.381

Saayman, M. \& Saayman, A., 2015, 'Economic impact of cultural events', South African Journal of Economic and Management Sciences 7(4), 629-642. https://doi.org/ 10.4102/sajems.v7i4.1294

Scholtz, M., Kruger, M. \& Saayman, M., 2013, 'Understanding the reasons why tourists visit the Kruger National Park during a recession', Acta Commercii 13(1), 1-9. https://doi.org/10.4102/ac.v13i1.168

Scholtz, M., Kruger, M., Saayman, M. \& Saayman, A., 2013, A marketing analysis and economic impact of the Africa Bike Week, unpublished research report, Tourism Research in Economic Environs and Society, North-West University, Potchefstroom.

Schouten, J.W. \& McAlexander, J.H., 1995, 'Subcultures of consumption: An ethnography of the new bikers', Journal of Consumer Research 22(1), 43-61. https://doi.org/10.1086/209434

SPSS Inc., 2012, IBM SPSS statistics version 21, International Business Machines Corp, Boston, MA.

Stead, D., Williams, J. \& Titheridge, H., 2000, 'Land use, transport and people: Identifying the connections', in K. Williams E. Burton \& M. Jenks (eds) Achieving sustainable urban form, pp. 174-186.

Steiner, R.L., 1994, 'Residential density and travel patterns: Review of the literature', in Issues in land use and transportation planning, models, and applications, Transportation research Record 1466, National Academy of Sciences.

Steyn, H.S., 2000, 'Practical significance of the difference in means', SA Journal of Industrial Psychology 26(3), 1-3. https://doi.org/10.4102/sajip.v26i3.711
Swanson, S.R., Davis, J.C. \& Zhao, Y., 2008, 'Art for art's sake? An examination of motives for arts performance attendance', Nonprofit and Voluntary Sector Quarterly 37(2), 300-323. https://doi.org/10.1177/0899764007310418

Thompson, W.E., 2009, 'Pseudo-deviance and the "new biker" sub culture: Hogs, blogs, leathers, and lattes', Deviant Behavior 30(1), 89-114. https://doi.org/ 10.1080/01639620802050098

Thompson, W.E., 2012, 'Don't call me "Biker Chick": Women motorcyclists redefining deviant identity', Deviant Behavior 33(1), 58-71. https://doi.org/10.1080/016396 25.2010 .548292

Thompson, W.E. \& Thompson, M.L., 2014, 'Mature motorcyclists: Violating age norms and loving it', Deviant Behavior 35(3), 233-242. https://doi.org/10.1080/0163962 5.2013 .822232

TREES, 2016, Marketing analysis of visitors to SA Bike festival, unpublished research report, Tourism Research in Economy Environs and Society, North West University, Potchefstroom.

Veno, A. \& Winterhalder, E., 2009, Biker chicks: The magnetic attraction of women to bad boys and motorbikes, Allen \& Unwin, Sydney.

Vlerah, V. \& Lea, A., 2013, 'Women's participation in endurance motorcycle challenges', doctoral dissertation, Bowling Green State University.

Warren, K., 1996, Women's voices in experiential education, Kendall/Hunt Publishing Co., Dubuque, IA.

Weinzimmer, D., Newman, P., Taff, D., Benfield, J., Lynch, E. \& Bell, P., 2014, 'Human responses to simulated motorized noise in national parks', Leisure Sciences 36(3), 251-267. https://doi.org/10.1080/01490400.2014.888022

Yeh, R.S. \& Lawrence, J.J., 1996, 'The use of factor analysis in management research: Sample size consideration', Hong Kong Journal of Business Management 14(1), 35-52. 